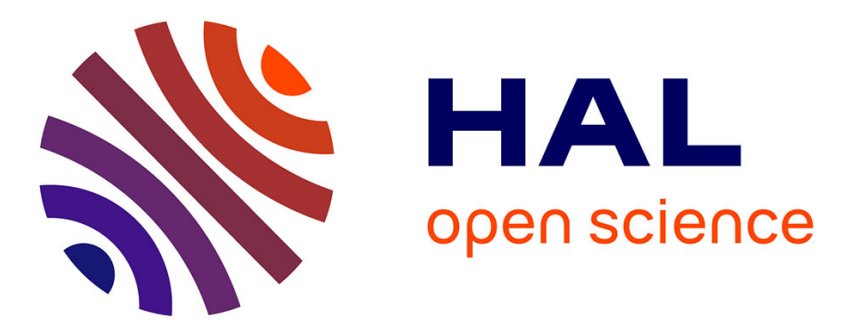

\title{
IMPURITY-DEFECT STRUCTURES OF Sn, Sb AND Te IMPLANTED $\alpha$-TIN SINGLE CRYSTALS
}

\author{
J. Petersen, S. Damgaard, G. Weyer, Jacques Chevallier, H. Nielsen
}

\section{To cite this version:}

J. Petersen, S. Damgaard, G. Weyer, Jacques Chevallier, H. Nielsen. IMPURITY-DEFECT STRUCTURES OF Sn, Sb AND Te IMPLANTED $\alpha$-TIN SINGLE CRYSTALS. Journal de Physique Colloques, 1980, 41 (C1), pp.C1-443-C1-444. 10.1051/jphyscol:19801172 . jpa-00219660

\section{HAL Id: jpa-00219660 https://hal.science/jpa-00219660}

Submitted on 1 Jan 1980

HAL is a multi-disciplinary open access archive for the deposit and dissemination of scientific research documents, whether they are published or not. The documents may come from teaching and research institutions in France or abroad, or from public or private research centers.
L'archive ouverte pluridisciplinaire HAL, est destinée au dépôt et à la diffusion de documents scientifiques de niveau recherche, publiés ou non, émanant des établissements d'enseignement et de recherche français ou étrangers, des laboratoires publics ou privés. 
IMPURITY-DEFECT STRUCTURES OF $S n$, SB AND Te IMPLANTED $\alpha-T I N$ SINGLE CRYSTALS

J.w. Petersen, S. Damgaard, G. Weyer, J. Chevallier and H.L. Nielsen

Institute of Physics, University of Aarhus, DK 8000 Acrhus C, Denmark.

\section{Introduction}

Mössbauer emission spectroscopy on the 24-keV r-transition of $119 \mathrm{Sn}$ has been applied previously to study impurity defects in group-IV semiconduct-

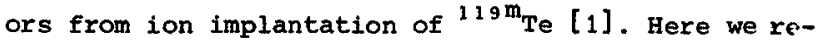
port on experiments with $\alpha$-tin single crystals involving implantations of ${ }^{119 \mathrm{~m}} \mathrm{Sn},{ }^{119} \mathrm{Sb}$, and ${ }^{119 \mathrm{~m}} \mathrm{Te}$,

\section{Experimental procedure}

The $\alpha$-tin single crystals were grown from a tin-mercury alloy. The $119 \mathrm{~m}$ Te activity was obtained fxom an irradiation of natural tin with $24 \mathrm{MeV}-$ particles. The $i^{119 \mathrm{~m}_{\mathrm{Te}}}\left(\mathrm{T}_{1 / 2}=4.7 \mathrm{~d}\right)$ was separated chemically from the tin target. ${ }^{119 \mathrm{~m}}$ Te decays to ${ }^{119} \mathrm{Sb}\left(\mathrm{T}_{1 / 2}=38 \mathrm{~h}\right)$ which in turn populates the Mossbauer level of ${ }^{119} \mathrm{Sn}$. The ${ }^{119} \mathrm{Sb}$ activity was milked from the ${ }^{119 \mathrm{~m}}$ Te. Implantations were performed at room temperature with an isotope separator at an energy of $80 \mathrm{keV}$. Doses of $\leq 10^{13}$ atoms $/ \mathrm{cm}^{2}$ were implanted for ${ }^{119 \mathrm{~m}} \mathrm{Te}$ and ${ }^{119} \mathrm{Sb}$ and $5 \cdot 10^{14} \mathrm{atoms} / \mathrm{cm}^{2}$ for ${ }^{119 \mathrm{~m}} \mathrm{Sn}$. Mössbauer emission spectra were measured at source temperatures between 77 and $300 \mathrm{~K}$ with a resonance counter of the parallel plate avr alanche type [2].

3. Experimental results and discussion Spectra from implantations of ${ }^{119} \mathrm{~m} \mathrm{Sn},{ }^{119} \mathrm{Sb}$, and ${ }^{119} \mathrm{~m}$ Te in $\alpha$-tin single crystals are displayed in Figure 1. The ${ }^{119} \mathrm{~m} \mathrm{Sn}$ spectrum has been decomposed into two emission lines (taking the known quar arupole splitting of the $\mathrm{SnO}_{2}$ absorber material into account for each line) as indicated in the figure.

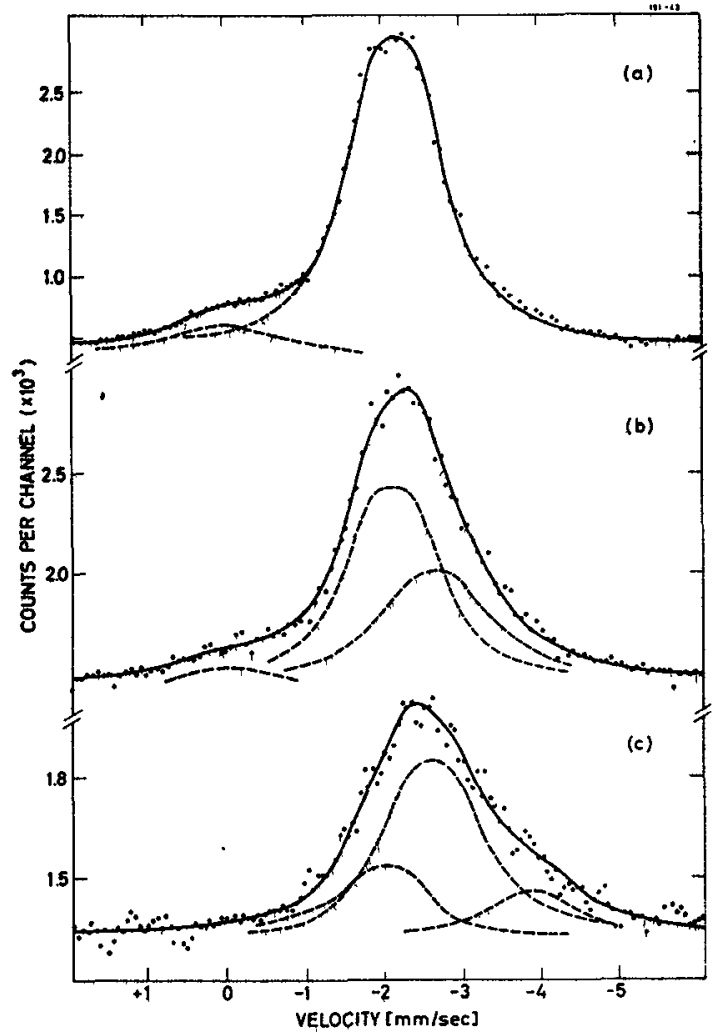

Figure 1 : Mössbauer spectra measured at source temperatures of $77 \mathrm{~K}$ for implantations of ${ }^{119 \mathrm{~m}} \mathrm{Sn}(\mathrm{a})$, $119 \mathrm{Sb}(\mathrm{b}), 119 \mathrm{~m}_{\mathrm{Te}}(\mathrm{c})$ in $\alpha-\mathrm{tin}$ single crystals.

Line 1 at $\delta_{1}=0.0 \mathrm{~mm} / \mathrm{s}$ is attributed to a minor fraction of $119 \mathrm{~m} \mathrm{Sn}$ implanted into the surface oxide layer of the sample. Line $2, \delta_{2}=2.16(5) \mathrm{mm} / \mathrm{s}$, stems from $119 \mathrm{~m}_{\mathrm{Sn}}$ atoms on substitutional lattice sites. Compared to an absorption spectrum measured for the unimplanted single crystal sample, this line is slightly broadened by $\sim 0.1 \mathrm{~mm} / \mathrm{s}$ and shifted to a higher isomer shift value by $\sim 0.1 \mathrm{~mm} / \mathrm{s}$. This is due 
to the influence of unannealed radiation damage from the implantation. The Debye temperature of line 2 is determined to $\theta_{2}=162(5) \mathrm{K}$ from temperature-dependent measurements. This is in agreement with a value of $\theta=162(5) \mathrm{K}$ for the undamaged material [3]. It should be mentioned that the shoulder on line 2 may indicate the presence of a weak third line at $\delta \approx 3.4 \mathrm{~mm} / \mathrm{s}$ in the spectrum. The spectrum from the ${ }^{119} \mathrm{Sb}$ implantation has been analysed in terms of three lines, a surface oxide line $\delta_{1}=0.0 \mathrm{~mm} / \mathrm{s}$, a substitutional line at $\delta_{2}=2.1 \mathrm{~mm} / \mathrm{s}$, and an additional line 3 at $\delta_{3}=$ $=2.6(1) \mathrm{mm} / \mathrm{s}$. This line is broadened by $\sim 0.3 \mathrm{~mm} / \mathrm{s}$ compared to line 2 and has a lower Debye temperature, $\theta_{3}=135(15) \mathrm{K}$. Analogous to conclusions drawn for a very similar line in silicon [4], this line is attributed to $\mathrm{Sn}$ atoms on (nearly) substitutional sites with one or two vacancies in the nearest neighbour shel1. The change in the Mössbauer parameters compared to an undisturbed substitutional site can be explained by the presence of dangling bonds at the $\mathrm{Sn}$ atoms.

Most likely the same line $\left(\delta=2.67(3), \Delta \mathrm{E}_{Q}=\right.$ $0.4(2) \mathrm{mm} / \mathrm{s}, \Theta=130(20) \mathrm{K}$ ) has been observed by Vogl and Vogl [5] for ${ }^{119 \mathrm{~m}} \mathrm{Sn}$ produced by neutron irradiation of $\alpha$-tin at low temperatures. This defect line annealed at $\sim 120 \mathrm{~K}$ in accordance with the fact that the defect is not formed in room temperature implantations of ${ }^{119 \mathrm{~m}} \mathrm{Sn}$. However, the vacancy defect is more stable when associated with $\mathrm{Sb}$, thus the same sn-vacancy structure may exist after the decay of Sb for times longer than the lifetime ( $\tau=27 \mathrm{~ns})$ of the Mössbauer level.

The spectrum for implanted $119 \mathrm{~m}_{\mathrm{Te}}$ is decomposed into four lines. Three with parameters very close to those for lines $1-3$ and an additional line at $\delta_{4}=3.9(1) \mathrm{mm} / \mathrm{s}$. For polycrystalline $\alpha-\mathrm{sn}$, which has a thicker surface oxide layer, this line was observed with much larger intensity [1]. This is in agreement with a tentative assignment of this line to an oxygen-containing defect structure.

4. Conclusions

Different ${ }^{119} \mathrm{Sn}$ defect structures have been obtained from implantations of $119 \mathrm{~m}_{\mathrm{Te}},{ }^{119} \mathrm{Sb}$, and $119 \mathrm{~m} s \mathrm{Sn} \alpha$-tin single crystals. Implantations of $119 \mathrm{~m} \mathrm{Sn}$ result in no specific defect line, however, the spectra are influenced by radiation damage and, due to the high implanted dose, the matexial may be amorphized. A vacancy associated impurity defect is formed in implantations of ${ }^{119} \mathrm{Sb}$ and - with even larger intensity - of ${ }^{119} \mathrm{~m}_{\mathrm{Te}}$. Additionally, in $119 \mathrm{~m}$ Te implantations a line is observed which is assigned to an oxygen containing defect.

This work has been supported by the Danish Natural Science Research Council.

\section{References}

[1] Weyer, G., Nylandsted Larsen, A., Deutch, B.I., Antoncik, E., and Nielsen, H.L., Inst.Phys. Conf.Ser. 31 (1977) 491

[2] Weyer, G., Mössb.Eff.Method. (eds.Gruvermann, I.J. and seidel, C.W.) 10 (1976) 301

[3] Petersen, J.W., thesis, Aarhus 1979

[4] Weyer, G., Nylandsted Larsen, A., Holm, N.E., and Nielsen, H.I. , to be published

[5] $\operatorname{Vog} 1, W$. and $\operatorname{Vog} 1$, G., J.Physique Colloq. 35 (1974) C $6-321$ and vogl, W., thesis, München 1974 